\title{
Downregulation of proinflammatory cytokines in HTLV-1-infected T cells by Resveratrol
}

\author{
Maria Pia Fuggetta ${ }^{1 *}$, Valentina Bordignon ${ }^{2 *}$, Andrea Cottarelli ${ }^{1}$, Beatrice Macchi ${ }^{3}$, Caterina Frezza ${ }^{4}$, \\ Paola Cordiali-Fei ${ }^{2}$, Fabrizio Ensoli ${ }^{2}$, Stefania Ciafrè ${ }^{1}$, Francesca Marino-Merlo ${ }^{5}$, Antonio Mastino ${ }^{1,5}$ \\ and Giampietro Ravagnan ${ }^{1}$
}

\begin{abstract}
Background: Human T-cell leukemia virus (HTLV-1) is a lymphotropic retrovirus associated to adult T cell leukemia (ATL) and to non-neoplastic inflammatory conditions affecting the central nervous system, lung or skin. The inflammatory disorders associated to HTLV-1 are mediated by different proinflammatory cytokines as IL-1a, IL-6, TNF-a. The release and the role of IL-17 is still debated. Aims of this study were to analyze IL-17 induction by HTLV-1 infection and to determine whether resveratrol (RES) is able to down regulate the pathway of cytokines production either in HTLV-1 chronically infected MT-2 cell line or in human CD4+ cells infected in vitro with HTLV-1.

Methods: MT-2 and HTLV-1 infected CD4+ cells were analyzed for proinflammatory cytokine production before or after RES treatment. The concentrations of IL-17, IL-1a, IL-6, and TNF-a were measured in cell culture supernatants by ELISA and SearchLight ${ }^{\text {TM }}$ technology. The IL-17 mRNA expression was evaluated by RT-PCR. NF-kB activation was detected by non-radioactive, Electro Mobility Shift Assay (EMSA). HTLV-1 RNA expression was detected by Realtime-PCR (RQ-PCR).
\end{abstract}

Results: We found that RES is capable of inducing a dose-dependent inhibition of IL-1a, IL-6 and TNF-a production in vitro and can down regulate the expression of IL-17 at both mRNA and protein levels in HTLV-1 infected cells. This effect was associated with a dose-dependent inhibition of the of the nuclear factor kappa-B (NF-kB) activity. Conversely, RES did not apparently affect HTLV-1 proliferation.

Conclusions: These results support the anti-inflammatory properties of RES, suggesting that it might be a useful therapeutic agent for the treatment of HTLV-1 related inflammatory diseases.

Keywords: Resveratrol, HTLV-1, Inflammatory cytokines

\section{Background}

The HTLV-1 virus infects approximately 10-20 million people worldwide [1]. Firstly identified as the etiological agent of ATL it was successively associated with progressive neurological disorders such as the HTLV-1-associated myelopathy/tropical spastic paraparesis (HAM/TSP), a chronic inflammatory disease of the central nervous system [2]. Other non-neoplastic inflammatory diseases such as uveitis, Sjögren syndrome,arthritis polymyositis and

\footnotetext{
* Correspondence: mariapia.fuggetta@ift.cnr.it; valentina.bordignon@ifo.gov.it ${ }^{1}$ Institute of Translational Pharmacology (IFT), National Research Council (CNR), Via Fosso del Cavaliere 100, 00133 Rome, Italy

${ }^{2}$ Laboratory of Clinical Pathology and Microbiology, San Gallicano Dermatologic Institute, Via Elio Chianesi, 53, 00144 Rome, Italy

Full list of author information is available at the end of the article
}

periodontitis, have been also recently associated to HTLV1 infection [3].

The HTLV-1 associated disorders HAM/TSP is characterized by spontaneous proliferation of CD4+ lymphocytes that harbor a provirus, which appear capable of promoting an active expansion of infected $\mathrm{T}$ cells. Inflammatory cytokines have been involved in the pathogenesis of HAM/TSP and high levels of IL-2, IFN- $\gamma$, and TNF- $\alpha$ appear to contribute to neurological damage in HAM/TSP patients [4]. HTLV-1 is capable to infect $\mathrm{CD} 4+\mathrm{T}$ and $\mathrm{CD} 8+\mathrm{T}$ cells in vitro [5] and to immortalize healthy CD4+ T cells that undergo to an active expansion and proliferation [6]. Although HTLV-1- 
associated disorders have been extensively studied, the mechanism by which HTLV-1 induces inflammatory conditions is still unclear. Moreover, the exact cellular and molecular events underlying the induction of chronic inflammation during infection is not completely understood.

The HTLV-1 provirus encodes a trans-acting factor (Tax) that operates in association with the activating transcription factor/CRE binding protein (ATF/CREB) to enhance virus transcription. Tax induces the expression of both viral and several cellular genes involved in different pathways [7]. Interestingly, HTLV-1 Tax has potent effects on infected $\mathrm{T}$ cells, including activation of nuclear factor NF-kB with a subsequent enhancement of cell proliferation and expression of different genes [8]. Peripheral blood mononuclear cells (PBMC) naturally infected by HTLV-1, such as in HAM/TSP disease, precociously express intracellular Tax protein and interferon- $\gamma$ (IFN- $\gamma$ ) in mitogen- stimulated short term culture, while the expression of IL-2 and TNF- $\alpha$ requires longer culture time $[9,10]$. In agreement with these experimental data, a recent study showed that an increase of IFN- $\gamma$ and TNF- $\alpha$ is involved in the tissue damage observed in clinical complications of HTLV-1 infection [11]. In HTLV-1-infected T cells, Tax up-regulates the expression of IL-17 and of its mRNA [12] and lymphocytes from a HAM/TSP patient have been shown to express in vitro detectable levels of Tax and IL-17 mRNA [13]. Thus, clinical and experimental data suggest that HTLV-I infected cells are prone to produce inflammatory cytokines which might in turn activate resident immune cells and amplify production of proinflammatory mediators within tissues in HTLV-1 infected patients. In light of this, individuals considered at risk of HTLV-1 related chronic inflammation could be optimal candidates to be treated with immunomodulatory agents as an adjuvant therapy.

Resveratrol (RES), or trans-3,5,4'-trihydroxystibene, is a polyphenolic, antifungal natural phytoalexin found in grapevines (Vitis vinifera) and a variety of other plants. RES has been shown to possess potent antioxidant and anticancer properties and has been investigated for its immunomodulating and anti-inflammatory capabilities [14-16]. In our previous studies [17] we have demonstrated that RES is able to modulate the expression of cytokines in CD4+ and CD8+ $\mathrm{T}$ cells stimulated with anti-CD3/anti-CD28, and could produce an inhibitory effect on IFN $-\gamma$, IL-2 and IL-4 production when used at high concentration. We have previously described [18] a significant inhibitory effects of RES, as well as of its derivative polydatin product, on the production of IL-17 in a model of cell inflammation in vitro. In addition, recent studies have reported that RES is active in a wide variety of virus infection $[19,20]$ revealing strong antiviral activity and an inhibitory effect on proinflammatory cytokine secretion in enterovirus 71 (EV71) infected cells [21].

The capability of RES in blocking nuclear factor kappa-B (NF-kB) mediated catabolic activity [14] makes him a promising therapeutic agent for the treatment of inflammatory conditions suggesting its potential clinical relevance in the therapy of inflammatory diseases.

This study was aimed at evaluating the in vitro effect of RES on the production of proinflammatory cytokines, including IL-17, in a HTLV-1 chronically infected cell line (MT-2), and in HTLV-1 infected immortalized human CD4+ T lymphocytes.

\section{Methods \\ Reagents}

Natural RES was extracted and kindly supplied by Dr. Fulvio Mattivi, (Fondazione Edmund Mach, IASMA) Italy. The purity of the compound tested by HPLC-MS, UV, and NMR was higher than $99 \%$ (method patented, Ravagnan et al. 2001, PCT/IB01/00983) [22]. RES was dissolved in dimethyl sulfoxide (DMSO, Sigma Chemical Co., St. Louis, USA) at $100 \mathrm{mM}$ stock solution. The stock solutions were stored at $-80{ }^{\circ} \mathrm{C}$ and diluted in culture medium just prior to use.

\section{Cells}

MT-2 cells, a HTLV-1 producing cell line derived from cord blood lymphocytes infected in vitro with HTLV-1 from infected patients [23], were grown in RPMI-1640 with $20 \%$ heat-inactivated fetal calf serum (FCSHyclone Laboratories, Logan, UK), (Hyclone Europe, Cramlington, UK) $2 \mathrm{mM}$ L-glutamine and penicillinstreptomycin (Life Technologies Ltd., Paisley, Scotland), hereafter referred to as complete medium (CM) and split weekly.

To assess HTLV-1 infection in vitro, lymphocytes were isolated from peripheral blood mononuclear cells (PBMC), obtained from healthy donors. Buffy coats were purified by Ficoll-hypaque gradient centrifugation (Sigma-Aldrich Corp) and CD4+/CD3+ cells were isolated by separation through immunomagnetic beads [6]. HTLV-1 infection was obtained by co-cultivating CD4+ lymphocytes with lethally irradiated (120 Gy, from a cesium Gamma cell 1000, Atomic Energy Canada) HTLV-I producing MT-2 cells at an acceptor: donor ratio of 3:1. Co-cultures were maintained in the presence of recombinant IL-2 (rIL-2, Hoffman-la Roche, Basel Switzerland) and split weekly The presence of HTLV-1 proviral DNA and of Tax/Rex mRNA in infected cells was determined at several time during the culture.

Cell growth and total number of viable cells were determined by the MTT assay and by the Trypan blue dye exclusion test, respectively, according to standard procedures. 


\section{Cytokine production and analysis}

MT-2 and HTLV-1 infected CD4+ cells were harvested, counted, suspended in CM and seeded into 24-well tissue culture plates (Falcon) in $1 \mathrm{ml} /$ well at a concentration of $1 \times 10^{5} \mathrm{cell} / \mathrm{ml}$. The plates were incubated at $37^{\circ}$ $\mathrm{C}$ in a $5 \% \mathrm{CO} 2$ humidified atmosphere for $30 \mathrm{~min}, 1,3$, 6, 12, 24, 48 or $72 \mathrm{~h}$. Each culture was set in triplicate. At each time, cells were analyzed for proinflammatory cytokine production. Culture supernatants of MT-2 and HTLV-1 infected CD4 + cells were collected as control for cytokine detection.

The concentrations of IL- $1 \alpha$, IL- 6 , and TNF- $\alpha$ were measured in undiluted cell culture supernatants in triplicate by multiplex enzyme-linked immunosorbent assay based on SearchLight ${ }^{\mathrm{m}}$ technology (Thermo Fisher Scientific Pierce Searchlight Products, Woburn, MA). The amount of signal produced is proportional to the amount of each protein in the sample detected with a cooled CCD camera. The assay [24] is capable of detecting target proteins at $\mathrm{pg} / \mathrm{ml}$ concentrations.

To detect IL-17 production, a quantitative sandwich enzyme immunoassay ( $R \& D$ Systems). technique specific for natural and recombinant human protein was used. According to the manufacturer, the detection limit of the assays was approximately $15.0 \mathrm{pg} / \mathrm{ml}$.

\section{RES treatment}

MT-2 and HTLV-1 infected CD4+ cells were harvested, counted, suspended in CM and seeded into 24-well tissue culture plates (Falcon) in $1 \mathrm{ml} /$ well volume at a concentration of $1 \times 10^{5} \mathrm{cell} / \mathrm{ml}$. Cells were incubated in the presence or in the absence of RES at final concentrations of $0.625,1.2,2.5,5,10,20,40 \mu \mathrm{g} / \mathrm{ml}$, or with DMSO alone as control. The plates were incubated for $0.5-48 \mathrm{~h}$ at $37{ }^{\circ} \mathrm{C}$ in a $5 \% \mathrm{CO} 2$. After each treatment, cell growth and viable cells were determined by Trypan blue exclusion test(data not shown). To evaluate the duration of the inhibitory effect of resveratrol on IL-17 production, MT-2 cells $\left(2.510^{4} \mathrm{cell} / \mathrm{ml}\right)$ were treated with $20-40 \mu \mathrm{g} /$ $\mathrm{ml}$ RES for $48 \mathrm{~h}$ and then washed and re-seeded into 24well tissue culture plates at a concentration of $1 \times 10^{5}$ cell/ ml. Culture supernatants were collected for IL-17 detection (ELISA kit Quantikine, h-IL-17 immunoassay, R\&D Systems, Minneapolis, USA).

\section{IL-17 mRNA expression through RT-PCR}

Total RNA was extracted from MT-2 and HTLV-1 infected cells using the RNeasy mini kit (Qiagen), according to manufacturer's instructions. RNA was extracted from either non-treated cells or from cells treated with $20 \mu \mathrm{g} / \mathrm{ml}$ of RES. Reverse transcription-PCR was carried out with the PCR CORE kit (Applied Biosystem, Roche) using random hexamers and $1 \mu \mathrm{g}$ total RNA for firststrand synthesis. The cDNA encoding IL-17 was amplified using the oligonucleotides IL-17 forward (5'-ATGACT CCTGGGAAGACCTCATTG-3') and IL-17 reverse (5'CTTAGGCCACATGGTGGACAATCG $-3^{\prime}$ ) by 40 PCR cycles of $95^{\circ}$ for $30 \mathrm{~s}, 70^{\circ}$ for $30 \mathrm{~s}$, and $72^{\circ}$ for $30 \mathrm{~s}$. As control, the constitutive human GAPDH cDNA was PCR amplified using the oligonucleotides GAPDH forward (5'-ATGGTTTACATGTTCCAATATGATTCC-3') and GAPDH reverse (5'-CTTACTCCTTGGAGGCCA TGTGGG-3'). The amplified products were electrophoresed on $2 \%$ agarose gel in $1 \times$ TAE (Tris acetate EDTA).

\section{Detection of HTLV-1 RNA expression by Real-time-PCR (RQ-PCR)}

RNA isolation was performed using EuroGOLD total RNA kit (Euroclone), according to the manufacturer's instructions. For RQ-PCR, $250 \mathrm{ng}$ of total RNA from each sample was reverse transcribed in a total volume of $20 \mu \mathrm{l}$ using the high-capacity cDNA reverse transcription kit (Applied Biosystems, CA, USA), according to the manufacturer's instructions. Amplification of specific PCR products was detected using the iQ SYBR Green Supermix (Bio-Rad, CA, USA). The RQ-PCR was performed in triplicate in a total reaction volume of $25 \mu \mathrm{l}$ containing $1 \mathrm{X}$ Sybr green RQ-PCR Mix, $150 \mathrm{nM}$ forward and reverse primers, and $200 \mathrm{ng} \mathrm{cDNA}$ as a template. Samples were heated for $10 \mathrm{~min}$ at $95{ }^{\circ} \mathrm{C}$ and were subjected to 40 cycles of PCR amplification, each cycle consisting of $15 \mathrm{~s}$ at $95{ }^{\circ} \mathrm{C}$ and $60 \mathrm{~s}$ at $60{ }^{\circ} \mathrm{C}$. For the detection of the HTLV-1 Tax/Rex region expression, RPXPR1 and RPX4 primers were used (Kinoshita and others 1989). Within each experiment, no-template control was used to verify any contamination, and the glucuronidase beta (GUSB) housekeeping gene (NM_000181; forward primer, 5'-CAGTTCCCTCCAGCTTCAATG-3', and reverse primer, 5'-ACCCAGCCGACAAAATGC-3') used as a reference gene, was run in parallel. Each run was completed with a melting curve analysis to confirm the specificity of amplification and lack of unspecific products and primer dimers. Quantification was performed using the $\mathrm{Ct}$ comparative method. Relative gene mRNA levels were calculated as follows: $2-[\Delta \mathrm{Ct}$ (sample) $-\Delta \mathrm{Ct}$ (calibrator $)]=2-\Delta \Delta \mathrm{Ct}$, where $\Delta \mathrm{Ct} \quad($ sample $)=[\mathrm{Ct}(\mathrm{tax} / \mathrm{gag}$ gene) - Ct (GUSB)] represents the difference, in threshold cycle number, between genes and GUSB. RQ-PCR experiments were run on RT CFX96 Real-Time PCR Detection System (Bio-Rad). All primers were purchased from Primm (Milano Italy).

\section{NF-kB binding assay}

NF-kB activation was detected by non-radioactive, Electro Mobility Shift Assay (EMSA), as previously described (Matteucci and others 2010). Briefly, aliquots of $10 \mu \mathrm{g}$ of nuclear extracts from $5 \times 10^{6}$ MT-2 cells, exposed or not to different concentrations of RES and prepared as 
previously described (Matteucci and others 2010), were incubated with 6 pmoles of biotin-labelled oligonucleotide probe containing the specific recognition sequence for NF-kB (AGTTGAGGGGACTTTCCCAGGC) and poly-dI-dC, to prevent unspecific reaction, in binding buffer. Binding reactions were incubated for $20 \mathrm{~min}$ at room temperature. The protein-DNA complexes were resolved on a $5 \%$ native polyacrylamide gel in TBE buffer and then transferred to "Zeta-probe GT Genomic" blotting membranes (Bio-Rad). Signal from biotinlabelled probe was detected using reagents provided in the "LightShift chemiluminescent EMSA module" (Pierce, Rockford, IL) followed by exposure to autoradiography film. The NIH Image s software (version 1.46r, Bethesda, MD, USA) was used to evaluate densitometry of scanned films from EMSA. The integrated density of all the pixels in the area of each signal was quantified and adjusted by a background subtraction of density in an adjacent blank area of the same size. This value represents the optical density of each shift in the films. Relative density was calculated as the ratio between RES-treated and vehicle-treated samples.

\section{Statistics}

All tests were run in triplicate or quadruplicate for each experimental condition and each experiment were repeated at least 3 times. Data were analyzed by a 1-way ANOVA with a post hoc Tukey's test.

\section{Results}

\section{Monitoring of cytokines production in MT-2 and HTLV-1 infected CD4 + lymphocytes}

In order to evaluate the production of cytokines induced by an HTLV-1 infection we analyzed the kinetics of IL17, IL- $1 \alpha$, IL- 6 and TNF- $\alpha$ production in the cell culture supernatants of MT-2 cells and of peripheral T CD4+ cells infected in vitro with HTLV-1. These determinations were performed by ELISA at different time points: after 30 min, 1 h, 3 h, $6 \mathrm{~h}, 12 \mathrm{~h}, 24 \mathrm{~h}, 48 \mathrm{~h}$ and $72 \mathrm{~h}$ of culture. Each time point was tested on quadruplicate samples and expressed as $\mathrm{pg} / \mathrm{ml}$ of culture supernatant.

The concentrations of IL- $1 \alpha$, IL-6,TNF- $\alpha$ and IL-17, detected in the supernatants of MT-2 cells and HTLV-1 infected $\mathrm{CD} 4+$ cells are described in Table 1. Data showed that all the cytokines reached higher levels in HTLV-1 infected CD4+ cells than in MT-2 cells. Although IL-17 was found in both cell cultures, with a peak around 24-48 h, it was detectable earlier in MT-2 than in HTLV-1 infected CD4 + lymphocytes. Differently from what observed for IL-17 release, IL-1 $\alpha$, IL- 6 and TNF- $\alpha$ level were detectable earlier in lymphocytes than in MT-2 cell supernatants. In particular, initial amounts of both TNF- $\alpha$ and IL- $1 \alpha$ in MT- 2 cell were very low and reached levels comparable to those detected in
Table 1 Proinflammatory cytokines production by MT-2 (A) and HTLV-1 infected CD4+ cells (B)

\begin{tabular}{|c|c|c|c|c|}
\hline \multicolumn{5}{|l|}{ A } \\
\hline Times & $\mid \mathrm{L}-1$ a $(\mathrm{pg} / \mathrm{ml})^{\mathrm{a}}$ & $\mathrm{IL}-6(\mathrm{pg} / \mathrm{ml})^{\mathrm{a}}$ & TNF-a $(p g / m l)^{a}$ & $\mathrm{IL}-17(\mathrm{pg} / \mathrm{ml})^{\mathrm{a}}$ \\
\hline $30 \mathrm{~m}$ & $2.7 \pm 0,35$ & $29 \pm 2.97$ & 0 & $27.1 \pm 1.8$ \\
\hline $3 \mathrm{~h}$ & $4.1 \pm 0,85$ & $83.5 \pm 4.03$ & $1.1 \pm 0.21$ & $21.6 \pm 1.75$ \\
\hline $6 \mathrm{~h}$ & $5.1 \pm 0.78$ & $110.6 \pm 14.64$ & $2.2 \pm 0.57$ & $22.7 \pm 0.8$ \\
\hline $24 \mathrm{~h}$ & $9.3 \pm 0.92$ & $103.8 \pm 12.09$ & $7.2 \pm 1.56$ & $69.8 \pm 4.2$ \\
\hline $48 \mathrm{~h}$ & $19.9 \pm 2.12$ & $101.9 \pm 13.79$ & $20.1 \pm 2.05$ & $62.9 \pm 3.6$ \\
\hline $72 \mathrm{~h}$ & $14.4 \pm 0.14$ & $105.1 \pm 15.20$ & $18.1 \pm 0.64$ & $57.7 \pm 8.2$ \\
\hline \multicolumn{5}{|l|}{ B } \\
\hline Times & $\mathbb{I L}-1 \quad a(p g / m l)^{a}$ & $\mathrm{IL}-6(\mathrm{pg} / \mathrm{ml})^{\mathrm{a}}$ & TNF-a $(\mathrm{pg} / \mathrm{ml})^{\mathrm{a}}$ & $\mathrm{IL}-17(\mathrm{pg} / \mathrm{ml})^{\mathrm{a}}$ \\
\hline $30 \mathrm{~m}$ & $26.5 \pm 1.13$ & $126.1 \pm 4.17$ & $28.0 \pm 2.55$ & 0 \\
\hline $1 \mathrm{~h}$ & $27.5 \pm 0.71$ & $118.9 \pm 2.26$ & $24.4 \pm 0.64$ & 0 \\
\hline $6 \mathrm{~h}$ & $25.7 \pm 0.49$ & $112.6 \pm 5.23$ & $29.3 \pm 1.48$ & 0 \\
\hline $24 \mathrm{~h}$ & $58.3 \pm 5.37$ & $111.4 \pm 2.76$ & $37.8 \pm 0.78$ & $26.8 \pm 1.35$ \\
\hline $48 \mathrm{~h}$ & $23.1 \pm 1.98$ & $113.7 \pm 2.90$ & $21.0 \pm 0.99$ & $49.8 \pm 2.8$ \\
\hline $72 \mathrm{~h}$ & $23.5 \pm 1.63$ & $114.1 \pm 2.97$ & $18.5 \pm 1.41$ & $45.7 \pm 3.1$ \\
\hline
\end{tabular}

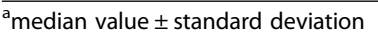

HTLV-1 infected CD4+ cells supernatants after 24-48 h of culture.

In the case of HTLV-1 infected CD4 cell line, the expression of the virus was relatively stable during the ongoing of the culture and, consequently, could not affect by itself the cytokine production.

\section{Effect of RES on proinflammatory cytokines production}

The inhibitory effects of RES on IL-1- $\alpha$, IL- 6 and TNF- $\alpha$ release in MT-2 cells, after treatment with $20 \mu \mathrm{g} / \mathrm{ml}$ and $40 \mu \mathrm{g} / \mathrm{ml}$ of RES for $1 \mathrm{~h}, 24 \mathrm{~h}$ and $48 \mathrm{~h}$ in comparison with untreated cells, are shown in Fig. 1. According to the length of treatment: a) no inhibition after $1 \mathrm{~h}$; b) significant, dose dependent reduction of IL- 6 and TNF- $\alpha$ $(100 \%)$ after $24 \mathrm{~h}$, at both concentrations $(P<0.01)$; c) significant reduction of IL- $1 \alpha$ and TNF- $\alpha$ production, at both concentrations $(P<0.01)$, and recovery of IL-6 production, after $48 \mathrm{~h}$. The inhibitory effect on TNF- $\alpha$ was visible also at the lowest concentrations of RES (from 0.612 to $2.5 \mu \mathrm{g} / \mathrm{ml}$ ) and lasted until $48 \mathrm{~h}$ (data not shown).

Levels of IL-17 were evaluated in culture supernatants from MT-2 cells and HTLV-1 infected CD4+ cells after $48 \mathrm{~h}$ of addition of RES at different concentrations $(0.612,1.25,2.5,5,10,20$ and $40 \mu \mathrm{g} / \mathrm{ml})$, cultures with DMSO alone were prepared as negative controls. Results, expressed in terms of IC50 inhibitory dose, i.e. the concentration of RES reducing $50 \%$ of IL-17 production, are illustrated in Fig. 2 Panel a. RES induced a dose-dependent inhibition on IL-17 production, reaching $100 \%$ of inhibition at $20 \mu \mathrm{g} / \mathrm{ml}$ in HTLV-1 infected 


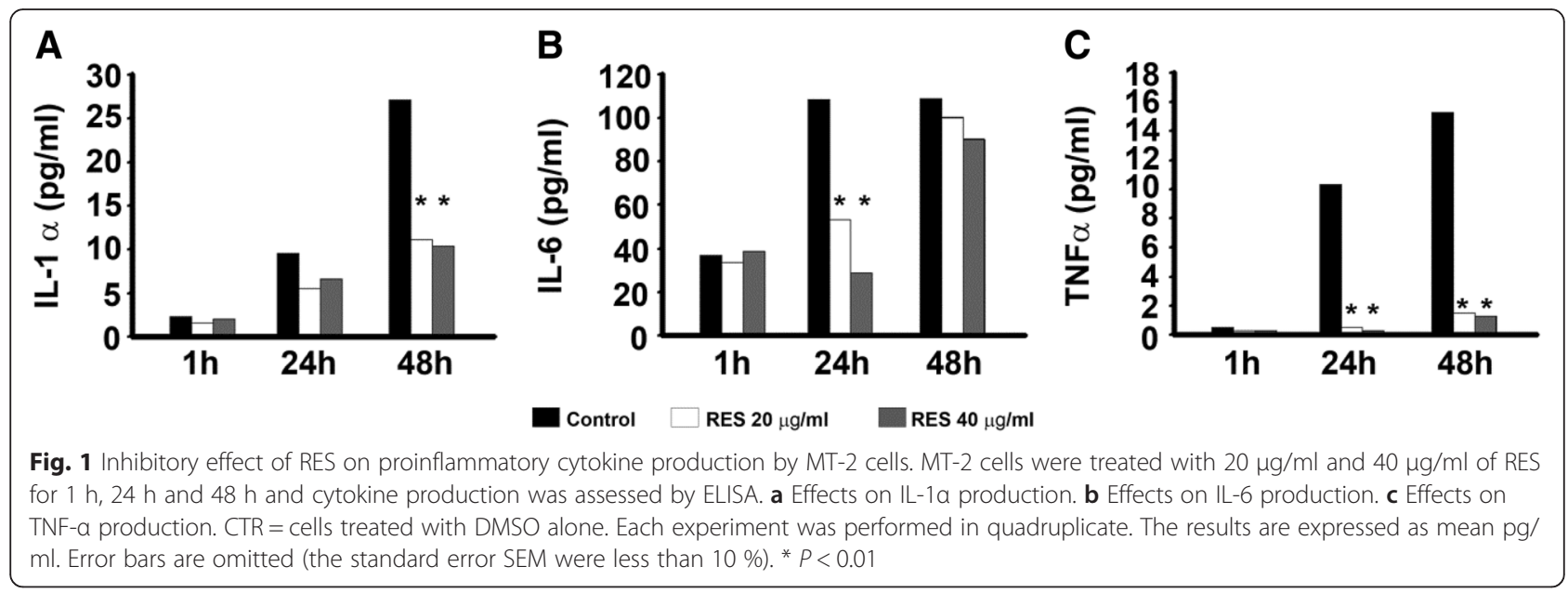

CD $4+$ cells, and at $40 \mu \mathrm{g} / \mathrm{ml}$ in MT-2 cells (data not shown). In any case the IC50 value is comparable both in MT-2 cells and HTLV-1 infected CD4 + .

The recovering from the inhibitory effect of RES $(20 \mu \mathrm{g} / \mathrm{ml})$ on IL-17 production was evaluated in supernatants of MT- 2 cells at $3 \mathrm{~h}, 6 \mathrm{~h}, 24 \mathrm{~h}$ and $48 \mathrm{~h}$ of culture, after RES removal. The IL-17 production was still significantly lower in treated cell cultures than in controls $(P<0.01)$ and this inhibitory effect lasted at least 48 h (Fig. 3).

\section{Effect of RES on the expression of IL-17 mRNA}

The effect of RES was evaluated on IL-17 mRNA using RT-PCR analysis. Results from a representative experiment are shown in Fig. 2 Panel b. RES at concentration of $20 \mu \mathrm{g} / \mathrm{ml}$ was clearly capable to down-regulate in $48 \mathrm{~h}$ the IL-17 mRNA in MT-2 cells and in HTLV-1 infected CD4+ lymphocytes. Accordingly with data showing the inhibition of IL-17 cytokine production (Fig. 2 Panel a), this result suggested that RES was most likely able to interfere with IL-17 release also at transcriptional level.

\section{Effects of RES on NF-kB activity in MT-2 cells}

With the aim of better understanding the mechanism responsible for the inhibitory effect of RES on IL-17 as well as its effect on the other cytokines assessed, we verified whether RES might directly affect the activation of the NF-kB complex. To this end, HTLV-1 chronically infected MT-2 cells were either treated with $20 \mu \mathrm{g} / \mathrm{ml}$ or $40 \mu \mathrm{g} / \mathrm{ml}$ of RES or exposed to vehicle (as negative control) and NF-kB activation was assessed as DNA-binding activity in nuclear lysates, harvested after 1 and $24 \mathrm{~h}$ from RES treatment, respectively, using a nonradioactive EMSA (Fig. 4). Equal amounts of nuclear extracts derived from equal amounts of viable cells from control or RES treated samples, were utilized, in order to avoid any bias related to differences in total cell number. A clear dose-dependent inhibition of NF-kB binding
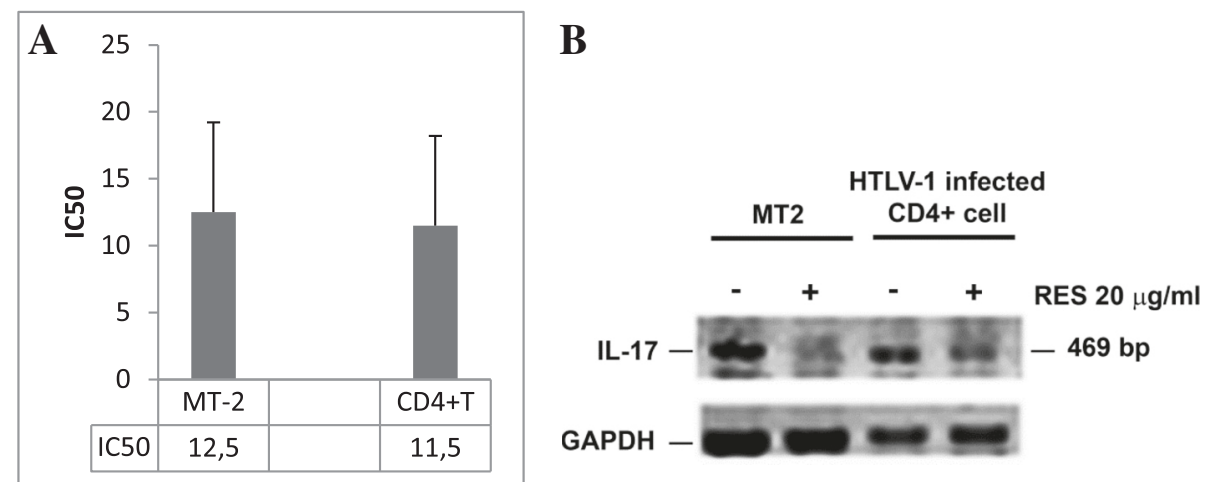

Fig. 2 Inhibitory effect of RES on IL-17 production. PANEL a show the inhibitory effect of different concentrations of RES on IL-17 production. MT-2 cells and HTLV- 1 infected CD4+ T cell cultures were treated with RES at 0.612,1.25,2.5,5,10,20 and $40 \mathrm{\mu g} / \mathrm{ml}$ for $48 \mathrm{~h}$ of culture. IL-17 production was assayed by ELISA and the results are expressed as IC50, i.e., the concentration of RES where the IL-17 production is reduced by $50 \%$. The bars represent the confidence limits. PANEL $\mathbf{b}$ show the Effect of RES on IL-17 transcription in MT-2 cells and HTLV-1 infected CD4+ cells. Cells were treated with RES at $20 \mathrm{\mu g} / \mathrm{ml}$ for $48 \mathrm{~h}$ and IL-17 transcription was assessed by RT-PCR. The image refers to visualization of IL-17 mRNA expression in DMSO treated MT-2 cells, RES-treated MT-2 cells, DMSO treated HTLV-1 infected CD4+ cells and RES-treated HTLV-1 infected CD4+ cells 

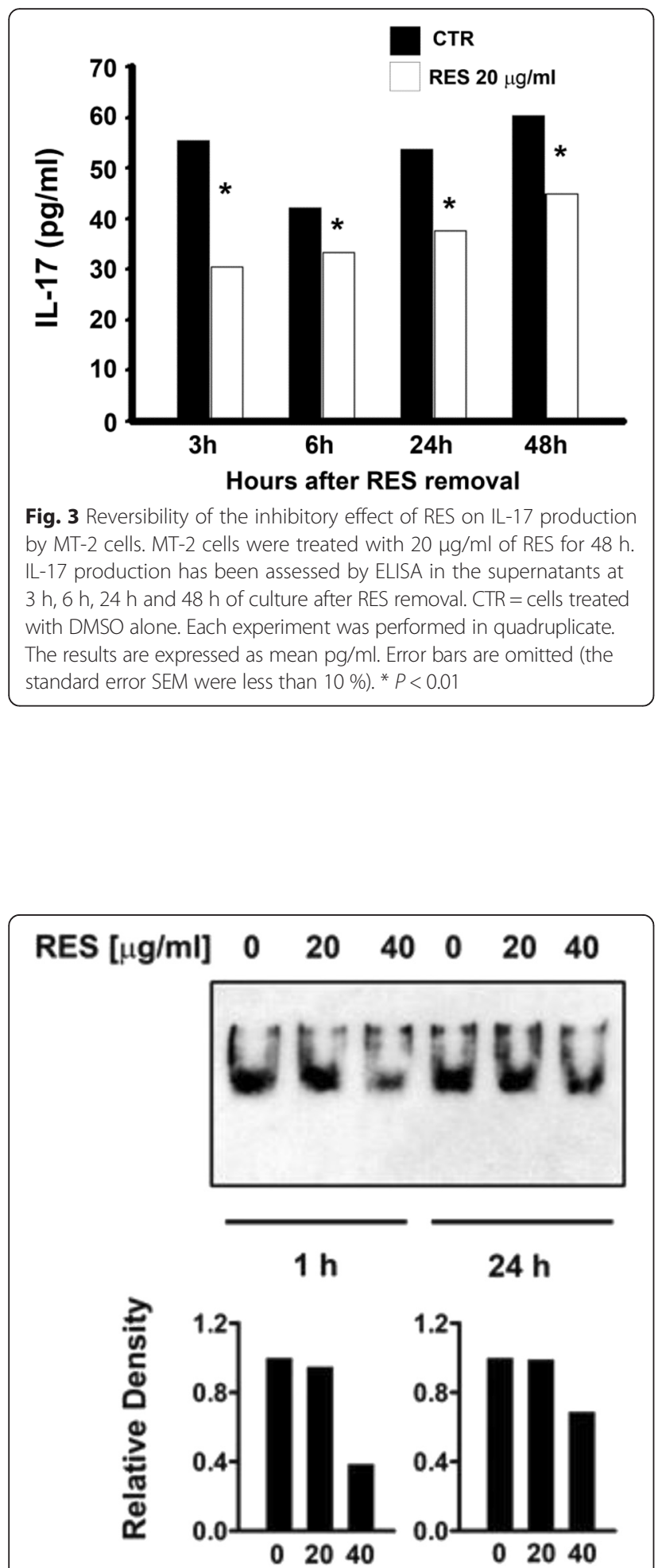

Fig. 4 Suppressive effect of RES on NF-kB activation in MT-2 cells. MT-2 cells were either treated with vehicle or treated with $20 \mu \mathrm{g} / \mathrm{ml}$ or $40 \mu \mathrm{g} / \mathrm{ml} \mathrm{RES}$ and after $1 \mathrm{~h}$ and $24 \mathrm{~h}, \mathrm{NF}-\mathrm{kB}$ complex activation was assayed by non-radioactive EMSA. The upper panel refers to the autoradiography film while the lower panels represent the relative density of the bands with respect to vehicle treated samples, from one representative experiments of the two performed with similar results activity was found after RES treatment. The suppressive effect was particularly evident at $40 \mu \mathrm{g} / \mathrm{ml}$ and early after exposure to the compound (at $1 \mathrm{~h}$ after treatment), as shown by the quantitative determination of the density of the bands (Fig. 4). Conversely RES at the concentration of 20 and $40 \mu \mathrm{g} / \mathrm{ml}$, did not induce downregulation of HTLV-1 Tax/Rex expression (see Fig. 5).

\section{Discussion}

In the present study we investigated the effects of RES on proinflammatory cytokines production from MT-2 cell line and from peripheral healthy donors CD4+ lymphocytes infected in vitro by HTLV-1. HTLV-1 infection is associated with systemic immune-mediated inflammatory diseases whose hallmarks include increased levels of IFN- $\gamma$, TNF- $\alpha$, and IL- 6 [2, 11, 25] and remarkable tissue damage [1]. The increased production of proinflammatory cytokines and the expansion of autoreactive $\mathrm{T}$ cells observed in HTLV-1-infected patients appear, at least in part, due to the lack of regulatory $\mathrm{T}$ cell function and a decreased ability of IL-10 and TGF $\beta$ to regulate the immune response [26]. In fact, IL-17 mRNA is highly expressed in HTLV-1-infected cells [13]. In infected $\mathrm{CD} 4^{+} \mathrm{T}$ cells, the Tax viral protein is capable of up-regulating the expression of IL-17, which, in turn, has the ability to stimulate the production of other inflammatory cytokines and chemokines, including IL-6, IL-8, GM-CSF and MCP-1 [26]. In previous studies we found that RES is able to counteract the production of IL-17 and Th1/Th2 cytokines in an inflammatory cell model in vitro $[17,18]$. Due to these anti-inflammatory and immunomodulating properties [27]. RES might represent a good candidate for chemoprevention strategies or for use in combination therapy in HTLV-1 related diseases.

In the present study we firstly analyzed the profiles of inflammatory cytokine production in vitro in two different cell systems, including the HTLV-1 transformed continuous MT-2 cell line and short term culture of CD4+ lymphocytes from healthy donors immortalized in our laboratory by HTLV-1.

We showed that HTLV-1 infected cells produce high amounts of inflammatory cytokines (Table 1), such as IL- $1 \alpha$, IL- 6 and TNF- $\alpha$, and that RES exerts an inhibitory effects on the HTLV-1 induced production of these cytokines (Fig. 4). In particular, TNF- $\alpha$ was strongly inhibited. Further experiments confirmed that RES can inhibit TNF- $\alpha$ and IFN- $\gamma$ in vitro even at very low concentrations (about $1 \mu \mathrm{g} \mathrm{RES} / \mathrm{ml}$ and $5 \mu \mathrm{g} / \mathrm{ml}$ RES respectively, data not shown). The exact role of an individual cytokine in the complex inflammatory milieu induced by HTLV-1 infection cannot be easily defined. It is well known that both TNF $-\alpha$ and IFN- $\gamma$ exert a synergistic effect on IL-17-induced production of IL-6 [28]. 


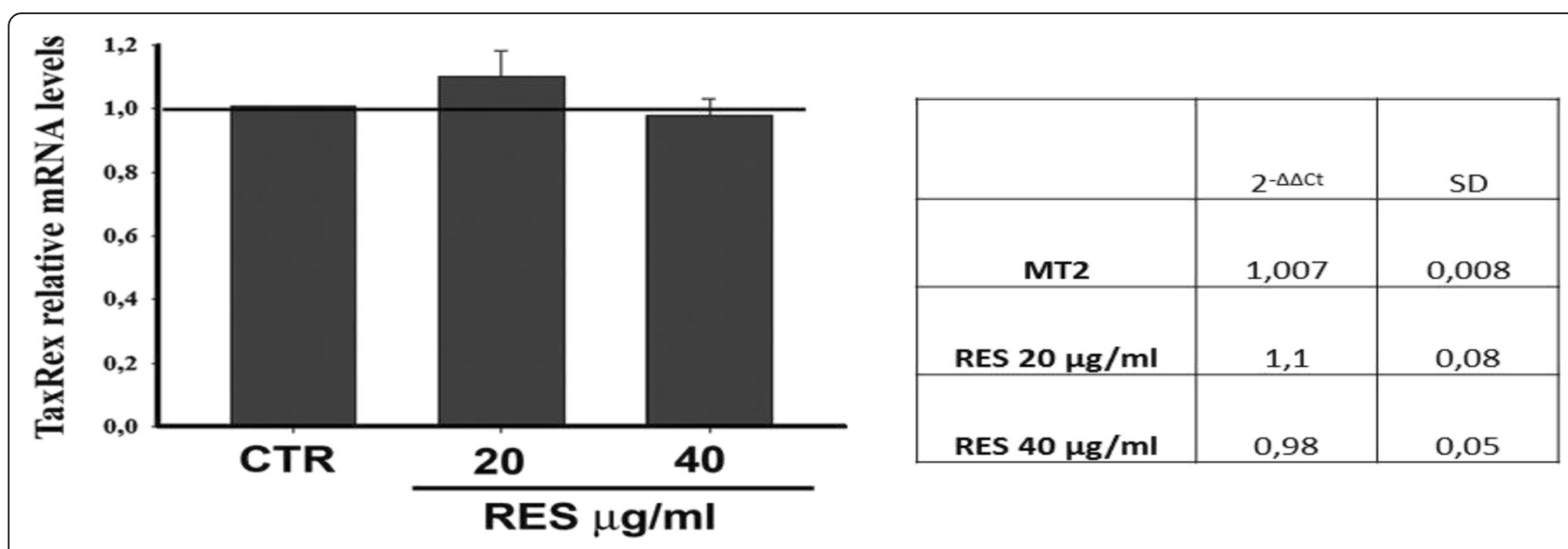

Fig. 5 Effect of RES on HTLV-1 Tax/Rex expression. MT-2 cells were either treated with vehicle (CTR) or with $20 \mu \mathrm{g} / \mathrm{ml}$ or $40 \mu \mathrm{g} / \mathrm{ml}$ RES and after $24 \mathrm{~h}$ Tax/Rex expression was evaluated through real-time PCR (RQ.PCR). The values were expressed as TaxRex relative mRNA levels in treated cells with respect to vehicle treated samples

IL-17 appears to play a key role in the cytokine circuitry induced by HTLV-1 infection, as shown in HAM/TSP patients [29]. However, conflicting results have been recently shown on the possible role of Th17 $\mathrm{T}$ cells and IL-17 production in HTLV-1 infected patients [30].

Our results showed that both HTLV-1 infected cell models spontaneously produce IL-17 in vitro although with different kinetics. In the MT-2 cell line the release of IL-17 was detected as early as $30 \mathrm{~min}$, whereas in HTLV-1 infected CD4+ T cells it was found after $12 \mathrm{~h}$ of culture (Fig. 1). Both cell types reached peak levels of IL17 production after 24 or $48 \mathrm{~h}$ in culture, respectively. These data are consistent with previous observations in HTLV-1-infected T cells showing that IL-17 mRNA is induced in association with Tax expression [13].

With the aim of investigating the effect of RES, IL-17 production was assessed in MT-2 and in HTLV-1 infected CD4+ T cells in the presence or in the absence of RES and found that in the presence of RES IL-17 is strongly reduced reaching a $100 \%$ inhibition both in MT-2 cells treated with RES $40 \mu \mathrm{g} / \mathrm{ml}$ (Fig. 2 Panel a) and in CD4+ infected T cells, treated with 20 and $40 \mu \mathrm{g} /$ $\mathrm{ml}$ of RES (Fig. 2 Panel b), respectively. In order to exclude that the low levels of cytokines might depend on cytotoxic effects of RES, although in our experimental conditions the concentrations of RES were well below the toxic concentrations cell viability was assessed after RES incubation by Trypan blue exclusion test (data not shown).

Figure 3 shows that the inhibitory effect of RES on IL17 production in MT-2 cells was still present up to $48 \mathrm{~h}$ after its removal at both protein and RNA levels (Fig. 5) in both cell models. Thus, these data indicate that the inhibitory effect of RES on IL-17 involve, at least in part, biochemical pathways independent from those governing the cell viability.
Molecular pathways presumably involved in the transcriptional activation of the IL-17 gene in HTLV-1infected cells include the Tax protein, which in turn depend on the CREB/ATF pathway and the interferon regulatory factor 4 (IRF4), a transcription factor that regulates IL-17 and IL-9, which is over-expressed in HTLV1-infected cells with a Th17 phenotype [13]. Moreover, a key role for the retinoic orphan receptor RORC, a Th17 transcription factor, has been also suggested in the regulation of IL-17 expression [13, 30]. The effect of RES on the above described molecular pathways is currently unknown and further studies are needed to understand this aspect. On the other hand, IL-17 receptor signaling induces the activation of NF-kB, which, in turn, results in elevated levels of inflammatory cytokines [31].

Recent studies suggest that NF-kB may play a key role in mediating RES effects since RES-induced inhibition of inflammatory cytokine production is achieved by suppressing NF-kB activation [32], although it has been argued that RES might hit multiple targets [33].

In the present study, we found that RES downregulate IL-17 in MT-2 cells through an inhibition of NF-kB activation (Fig. 4). Although it is not possible, at the moment, to trace the cascade of events triggered by RES and leading to the down-regulation of IL-17 and other inflammatory cytokines in HTLV-1 infected cells, nevertheless, based on our results and on existing literature [34-36], it appears conceivable that a strict connection exists between RES-induced inhibition of the inflammatory cytokine circuitry and the down regulation of NF-kB.

In addition, it is well recognized that the HTLV-1 Tax protein primarily targets the IkB kinase complex, resulting in persistent activation of NF-kB and upregulation of its responsive genes that, in turn, are crucial for $\mathrm{T}$ cell survival and cell cycle progression [34]. It has been 
shown that RES inhibits NF-kB and modulates IkB kinase and this may contribute to the inhibition of inflammatory cytokines $[35,36]$. Thus, compelling evidence suggest that the inhibition of NF-kB by RES represents a key step for the downregulation of inflammatory cytokines. However, whether this depend or not on IL-17, is still an open question.

On the other hand, the failure of RES in suppressing IL- 6 production could be due to the fact that in addition to NF-kB mediated transcription, the IL- 6 gene can be activated by alternative mechanisms [37].

RES has been shown to inhibit the replication of herpes viruses as well as the growth of EBV-immortalized cell lines and polyomavirus [38, 39]. In HTLV-1 infection, RES has been shown to inhibit the growth of virusinfected cell lines by down-regulating survivin expression [40]. In our study the treatment of MT-2 cells with RES was unable to affect HTLV-1 expression. Similarly Tang et al. [41] have shown that low Res concentrations did not significantly inhibited virus expression in MT-2 cells in vitro. Conversely they reported that increasing amount of Res inhibited Tax-mediated LTR transactivation in SIRT-1 overexpressing HEK293 cells (Tang et al.). These studies suggest that Res is able to abrogate Tax transactivation only under condition of LTR overexpression, in presence of SIRT-1 deacetylase, while in physiological conditions the inhibitory effect of Res on HTLV-1 expression is rather cell type dependent [41].

More recently, it has been shown that RES at high concentration $(50-100 \mu \mathrm{M})$ had potent antiproliferative effect on ATL cells [42].

In our study we found that that although RES did not inhibit HTLV-1 expression (data not shown), and beside an anti-proliferative effect toward HTLV-I infected cells exerted at high concentrations, at lower concentrations RES can exert an evident, dose-dependent antiinflammatory activity. These results strongly suggest RES can either act on cell growth and the inflammatory circuitries through distinct mechanisms.

\section{Conclusions}

Anti-retroviral agents used for HIV have partially improved the prognosis of ATL, but little effect has been shown on HAM/TSP [43]. Moreover, an effective therapy for HTLV-1 associated diseases still represent an unmet need. Results of the present study suggest that RES can exert an anti-inflammatory activity on HTLV-1 infected cells at low doses, in association with a suppressive effect on NF-kB activation. Taken together, these results suggest that RES, or its derivative, given also its safety profile in clinical trials $[44,45]$, might represent a promising therapeutic agent, in combination with both anti-inflammatory and/or antiretroviral drugs, for the treatment of HTLV-1related diseases, including HAM/TSP.

\section{Authors' contribution}

MF, FE, VB: Conception and design, acquisition, analysis, interpretation of data and drafting the manuscript. AC, VB: Conception and design, acquisition, of data by cell culture, drug treatment, IL-17 bioassay. VB, PCF: Conception and design, acquisition of data and interpretation of proinflammatory cytokines assay. SC: Conception and design, analysis and interpretation of data about IL-17 RT-PCR assay. CF: Conception and design of data by real time PCR assay. FM: Conception, design, acquisition and analysis of data and interpretation of the NF-kB assay. AM, BM, FE: general discussion on the experimental design and revision of the manuscript. GR: analysis and interpretation of data. All authors read and approved the final manuscript.

\section{Competing interests}

The authors declare that there is no conflict of interest that could be perceived as prejudicing the impartiality of the reported research.

\section{Author details}

${ }^{1}$ Institute of Translational Pharmacology (IFT), National Research Council (CNR), Via Fosso del Cavaliere 100, 00133 Rome, Italy. ${ }^{2}$ Laboratory of Clinical Pathology and Microbiology, San Gallicano Dermatologic Institute, Via Elio Chianesi, 53, 00144 Rome, Italy. ${ }^{3}$ Department of System Medicine, University of Rome "Tor Vergata", Via Montpellier 1, 00133 Rome, Italy. ${ }^{4}$ Department of Biochemical Science and Surgery, University of Rome "Tor Vergata", Via Montpellier 1, 00133 Rome, Italy. ${ }^{5}$ Department of Chemical, Biological, Pharmaceutical, and Environmental Sciences, University of Messina, 98166 Messina, Italy.

Received: 14 April 2016 Accepted: 14 July 2016

Published online: 22 July 2016

\section{References}

1. Cook LB, Melamed A, Demontis MA, Laydon DJ, Fox JM, Tosswill JH, de Freitas D, Price AD, Medcalf JF, Martin F, Neuberger JM, Bangham CR, Taylor GP. Rapid dissemination of human T-lymphotropic virus type 1 during primary infection in transplant recipients. Retrovirology. 2016;13(1):3.

2. Goncalves DU, Proietti FA, Barbosa-Stancioli EF, Martins ML, Ribas JG, Martins-Filho OA, Teixeira-Carvalho A, Peruhype-Magalhaes V, CarneiroProietti AB. HTLV-1-associated myelopathy/tropical spastic paraparesis (HAM/TSP) inflammatory network. Inflamm Allergy Drug Targets. 2008;7(2): 98-107.

3. Martin F, Taylor GP, Jacobson S. Inflammatory manifestations of HTLV-1 and their therapeutic options. Expert Rev Clin Immunol. 2014;10(11):1531-46.

4. Kubota R, Kawanishi T, Matsubara H, Manns A, Jacobson S. Demonstration of human T lymphotropic virus type I (HTLV-I) tax-specific CD8+ lymphocytes directly in peripheral blood of HTLV-I-associated myelopathy/ tropical spastic paraparesis patients by intracellular cytokine detection. J Immunol. 1998;161(1):482-8.

5. Gross C, Thoma-Kress AK. Molecular Mechanisms of HTLV-1 Cell-to-Cell Transmission. Viruses. 2016;8(3):74. doi:10.3390/v8030074.

6. Tricarico M, Macchi B, D'Atri S, Morrone S, Bonmassar E, Fuggetta MP, Graziani G. In vitro infection of CD4+ T lymphocytes with HTLV-I generates immortalized cell lines coexpressing lymphoid and myeloid cell markers. Leukemia. 1999;13(2):222-9.

7. Currer R, Van Duyne R, Jaworski E, Guendel I, Sampey G, Das R, Narayanan A, Kashanchi F. HTLV tax: a fascinating multifunctional co-regulator of viral and cellular pathways. Front Microbiol. 2012;3:406.

8. Qu Z, Xiao G. Human T-cell lymphotropic virus: a model of NF-kappaBassociated tumorigenesis. Viruses. 2011;3(6):714-49.

9. Hanon E, Goon P, Taylor GP, Hasegawa H, Tanaka Y, Weber JN, Bangham CR. High production of interferon gamma but not interleukin-2 by human T-lymphotropic virus type l-infected peripheral blood mononuclear cells. Blood. 2001;98(3):721-6.

10. Kambara C, Nakamura T, Furuya T, Nishiura Y, Kawakami A, Ichinose K, Shirabe S, Eguchi K. Increased sialyl Lewis $(\mathrm{X})$ antigen-positive cells mediated by HTLV-1 infection in peripheral blood CD4(+) T lymphocytes in patients with HTLV-1-associated myelopathy. J Neuroimmunol. 2002;125(1-2):179-84.

11. Luna T, Santos SB, Nascimento M, Porto MA, Muniz AL, Carvalho EM, Jesus AR. Effect of TNF-alpha production inhibitors on the production of proinflammatory cytokines by peripheral blood mononuclear cells from HTLV1-infected individuals. Braz J Med Biol Res. 2011;44(11):1134-40. 
12. Dodon MD, Li Z, Hamaia S, Gazzolo L. Tax protein of human T-cell leukaemia virus type 1 induces interleukin 17 gene expression in T cells. J Gen Virol. 2004;85(Pt 7):1921-32.

13. Refaat A, Zhou Y, Suzuki S, Takasaki I, Koizumi K, Yamaoka S, Tabuchi Y, Saiki I, Sakurai H. Distinct roles of transforming growth factor-beta-activated kinase 1 (TAK1)-c-Rel and interferon regulatory factor 4 (IRF4) pathways in human T cell lymphotropic virus 1-transformed Thelper 17 cells producing interleukin-9. J Biol Chem. 2011;286(24):21092-9.

14. Catalgol B, Batirel S, Taga Y, Ozer NK. Resveratrol: French paradox revisited. Front Pharmacol. 2012;3:141.

15. Fuggetta MP, Lanzilli G, Tricarico M, Cottarelli A, Falchetti R, Ravagnan G, Bonmassar $\mathrm{E}$. Effect of resveratrol on proliferation and telomerase activity of human colon cancer cells in vitro. J Exp Clin Cancer Res. 2006;25(2):189-93.

16. Fuggetta MP, D'Atri S, Lanzilli G, Tricarico M, Cannavo E, Zambruno G, Falchetti $R$, Ravagnan $G$. In vitro antitumour activity of resveratrol in human melanoma cells sensitive or resistant to temozolomide. Melanoma Res. 2004;14(3):189-96.

17. Falchetti R, Fuggetta MP, Lanzilli G, Tricarico M, Ravagnan G. Effects of resveratrol on human immune cell function. Life Sci. 2001;70(1):81-96.

18. Lanzilli G, Cottarelli A, Nicotera G, Guida S, Ravagnan G, Fuggetta MP. Antiinflammatory effect of resveratrol and polydatin by in vitro IL-17 modulation. Inflammation. 2012;35(1):240-8.

19. Campagna M, Rivas C. Antiviral activity of resveratrol. Biochem Soc Trans. 2010;38(Pt 1):50-3. Review.

20. Berardi V, Ricci F, Castelli M, Galati G, Risuleo G. Resveratrol exhibits a strong cytotoxic activity in cultured cells and has an antiviral action against polyomavirus: potential clinical use. J Exp Clin Cancer Res. 2009;1(28):96.

21. Zhang L, Li Y, Gu Z, Wang Y, Shi M, Ji Y, Sun J, Xu X, Zhang L, Jiang J, Shi $W$. Resveratrol inhibits enterovirus 71 replication and pro-inflammatory cytokine secretion in rhabdosarcoma cells through blocking IKKs/NF-kB signaling pathway. PLoS One. 2015;10(2):e0116879.

22. Ravagnan G, Falchetti R, Lanzilli G, Fuggetta MP, Tricarico M, Mattivi F. Method for the extraction of pharmaceutically active product from spermatophyte plants, products thus obtained and their use in the medical field, in particular as substances with immunomodulating activity. (PCT/ IB01/00983) 2001.

23. Hashikura Y, Umeki K, Umekita K, Nomura H, Yamamoto I, Hasegawa H, Yanagihara K, Okayama A. The diversity of the structure and genomic integration sites of HTLV-1 provirus in MT-2 cell lines. Hum Cell. 2016;3.

24. Moody MD, Van Arsdell SW, Murphy KP, Orencole SF, Burns C. Array-based ELISAs for high-throughput analysis of human cytokines. Biotechniques. 2001;31(1):186-90. 192-4.

25. Carvalho EM, Bacellar O, Porto AF, Braga S, Galvao-Castro B, Neva F. Cytokine profile and immunomodulation in asymptomatic human Tlymphotropic virus type 1-infected blood donors. J Acquir Immune Defic Syndr. 2001;27(1):1-6.

26. Santos SB, Porto AF, Muniz AL, Luna T, Nascimento MC, Guerreiro JB, Oliveira-Filho J, Morgan DJ, Carvalho EM. Modulation of T cell responses in HTLV-1 carriers and in patients with myelopathy associated with HTLV-1. Neuroimmunomodulation. 2006;13(3):145-51.

27. Poulsen MM, Fjeldborg K, Ornstrup MJ, Kjær TN, Nøhr MK, Pedersen SB. Resveratrol and inflammation: Challenges in translating pre-clinical findings to improved patient outcomes. Biochim Biophys Acta. 2015;1852:1124-36.

28. Jovanovic DV, Di Battista JA, Martel-Pelletier J, Jolicoeur FC, He Y, Zhang M, Mineau F, Pelletier JP. IL-17 stimulates the production and expression of proinflammatory cytokines, IL-1beta and TNF-alpha, by human macrophages. J Immunol. 1998;160(7):3513-21.

29. Starling AL, Martins-Filho OA, Lambertucci JR, Labanca $L$, de Souza Pereira SR, Teixeira-Carvalho A, Martins ML, Ribas JG, Carneiro-Proietti AB, Goncalves DU. Proviral load and the balance of serum cytokines in HTLV-1asymptomatic infection and in HTLV-1-associated myelopathy/tropical spastic paraparesis (HAM/TSP). Acta Trop. 2013;125(1):75-81.

30. Leal FE, Ndhlovu LC, Hasenkrug AM, Bruno FR, Carvalho KI, Wynn-Williams $H$, Neto WK, Sanabani SS, Segurado AC, Nixon DF, Kallas EG. Expansion in CD39(+) CD4(+) immunoregulatory t cells and rarity of Th17 cells in HTLV-1 infected patients is associated with neurological complications. PLoS Negl Trop Dis. 2013;7(2), e2028.

31. Beringer A, Noack M. Miossec P IL-17 in Chronic Inflammation: From Discovery to Targeting. Trends Mol Med. 2016;22(3):230-41.

32. Qureshi AA, Guan XQ, Reis JC, Papasian CJ, Jabre S, Morrison DC, Qureshi N. Inhibition of nitric oxide and inflammatory cytokines in LPS-stimulated murine macrophages by resveratrol, a potent proteasome inhibitor. Lipids Health Dis. 2012;11:76.

33. De Leo A, Arena G, Lacanna E, Oliviero G, Colavita F, Mattia E. Resveratrol inhibits Epstein Barr Virus lytic cycle in Burkitt's lymphoma cells by affecting multiple molecular targets. Antiviral Res. 2012;96(2):196-202.

34. Cheng $H$, Ren $T$, Sun SC. New insight into the oncogenic mechanism of the retroviral oncoprotein Tax. Protein Cell. 2012;3(8):581-9.

35. Kumar A, Sharma SS. NF-kappaB inhibitory action of resveratrol: a probable mechanism of neuroprotection in experimental diabetic neuropathy. Biochem Biophys Res Commun. 2010;394(2):360-5.

36. Kundu JK, Shin YK, Kim SH, Surh YJ. Resveratrol inhibits phorbol esterinduced expression of COX-2 and activation of NF-kappaB in mouse skin by blocking IkappaB kinase activity. Carcinogenesis. 2006;27(7):1465-74.

37. Liu X, Jones GW, Choy EH, Jones SA. The biology behind interleukin-6 targeted interventions. Curr Opin Rheumatol. 2016:28(2):152-60.

38. Chen X, Qiao H, Liu T, Yang Z, Xu L, Xu Y, Ge HM, Tan RX, Li E. Inhibition of herpes simplex virus infection by oligomeric stilbenoids through ROS generation. Antiviral Res. 2012;95(1):30-6.

39. Espinoza JL, Takami A, Trung LQ, Kato S, Nakao S. Resveratrol prevents EBV transformation and inhibits the outgrowth of EBV-immortalized human B cells. PLoS One. 2012;7(12), e51306.

40. Hayashibara T, Yamada Y, Nakayama S, Harasawa H, Tsuruda K, Sugahara K, Miyanishi T, Kamihira S, Tomonaga M, Maita T. Resveratrol induces downregulation in survivin expression and apoptosis in HTLV-1-infected cell lines: a prospective agent for adult T cell leukemia chemotherapy. Nutr Cancer. 2002:44(2):193-201.

41. Tang HM, Gao WW, Chan CP, Cheng Y, Deng JJ, Yuen KS, Iha H, Jin DY, Virol J. SIRT1 Suppresses Human T-Cell Leukemia Virus Type 1 Transcription. J Virol. 2015;89(16):8623-31.

42. Suzuki Y, Ito S, Sasaki R, Asahi M, Ishida Y. Resveratrol suppresses cell proliferation via inhibition of STAT3 phosphorylation and Mcl-1 and CIAP-2 expression in HTLV-1-infected T cells. Leuk Res. 2013;37(12):1674-9.

43. Macchi B, Balestrieri E, Ascolani A, Hilburn S, Martin F, Mastino A, Taylor GP. Susceptibility of primary HTLV-1 isolates from patients with HTLV-1associated myelopathy to reverse transcriptase inhibitors. Viruses. 2013;5: 469-83.

44. Patel KR, Scott E, Brown VA, Gescher AJ, Steward WP, Brown K. Clinical trials of resveratrol. Ann N Y Acad Sci. 2011;1215:161-9.

45. Park EJ, Pezzuto JM. The pharmacology of resveratrol in animals and humans. Biochim Biophys Acta. 2015;1852(6):1071-113.

\section{Submit your next manuscript to BioMed Central and we will help you at every step:}

- We accept pre-submission inquiries

- Our selector tool helps you to find the most relevant journal

- We provide round the clock customer support

- Convenient online submission

- Thorough peer review

- Inclusion in PubMed and all major indexing services

- Maximum visibility for your research

Submit your manuscript at www.biomedcentral.com/submit
) Biomed Central 